DOI https://doi.org/10.32782/2305-9389/2020.22.14

УДК 321.6/.8-057.341

Стрелков Владислав,

аспірант кафедри політології, управління та державної безпеки Волинського національного університету імені Лесі Українки

\title{
МЕТОДОЛОГІЯ ДОСЛІДЖЕННЯ ТЕХНОЛОГІЙ ДЕЛЕГІТИМАЦІЇ ПРЕЗИДЕНТСЬКОЇ ВЛАДИ
}

\begin{abstract}
Нестабільність є визначальною рисою політичного прочесу в Україні. Відсутність тривалої традииї суверенного державотворення в умовах сталої демократії заклала підвалини проблем легітимності політичної влади в Украӥні на сучасному етапі державного будівництва. Проблеми, пов'язані з утратою підтримки та довіри громадян, є особливо відчутними для незміцнілих політичних інститутів українського суспільства. За часи незалежності криза легітимності політичної влади набула всеохоплюючого характеру в українській політичній системі. Це призвело до формування процесу делегітимації політичної влади. Найбільших репутаційних утрат від процесу делегітимачії зазнав інститут президентства. Кульмінацією ичих проиесів для інституту президентства в Україні стали подї Револючії гідності 2013-2014 рр. та обрання президентом «не політика» В. Зеленського у 2019 р, яке стало проявом тотальної делегітимацї украӥнської політичної еліти.

Проблеми делегітимаиії президентської влади значною мірою залишаються поза увагою українського наукового співтовариства. Про ие свідчить недостатнє висвітлення означеної проблеми у вітчизняній науковій літературі. Однак актуальність кризових явищ в украӥнській політичній системі та невирішеність проблем делегітимації президентської влади в політичному процесі України стимулюють наукову зацікавленість иією проблематикою. 3 огляду на иче, автор пропонує інструментарій, який стане у нагоді в наукових розвідках, предметом яких є делегітимація президентської влади.

У статті розглянуто два рівня методології: загальнонауковий та конкретно-науковий. У рамках загальнонаукового рівня методології проаналізовано можливості застосування для дослідження технологій делегітимації президентської влади таких підходів: інституційного, історичного, соиіокультурного, аксіологічного, системного, біхевіорального, діяльнісного, синергетичного. У рамках конкретно-наукового рівня методології встановлено евристичний потенціал таких спеціальних методів: спостереження, статистичного аналізу, математичного моделювання, психологічного аналізу, політичного прогнозування, політичного моделювання, контент-аналізу, case study.
\end{abstract}

Ключові слова: методологія, методологічний підхід, метод, президентська влада, легітимність, політичні технології, делегітимація, технологї̈ делегітимації президентської влади.

\section{Strelkov Vladyslav. Methodology of research of technologies of delegitimation of presidential power}

Instability is a defining feature of the political process in Ukraine. The absence of a long tradition of sovereign statebuilding in a stable democracy laid the foundations for the problems of the legitimacy of political power in Ukraine at the present stage of state-building. The problems associated with the loss of support and trust of citizens are particularly acute for the weakened political institutions of Ukrainian society. Since independence, the crisis of legitimacy of political power has become pervasive in the Ukrainian political system. This led to the constitution of the process of delegitimation of political power. The institution of the presidency suffered the greatest reputational losses from the delegitimation process. The culmination of these processes for the institution of the presidency in Ukraine were the events of the Revolution of Dignity 2013-2014 and the election of «non-politician»V. Zelenskyi in 2019, which was a manifestation of the total delegitimation of the Ukrainian political elite.

The problems of delegitimation of presidential power largely remain out of the attention of the Ukrainian scientific community. This is evidenced by insufficient coverage of this problem in the domestic scientific literature. However, the urgency of the crisis in the Ukrainian political system and the unresolved problems of delegitimation of presidential power in the political process of Ukraine stimulate scientific interest in this issue. With this in mind, the author offers tools that will be useful in scientific intelligence, the subject of which is the delegitimation of presidential power.

The article considers two levels of methodology: general scientific and specific scientific. Within the general scientific level of the methodology the possibilities of application of the following approaches for research of delegitimation of presidential power are analyzed: institutional, historical, sociocultural, axiological, systemic, behavioral, activity, synergetic. Within the specific scientific level of the methodology, the heuristic potential of the following special methods is established: observation, statistical analysis, mathematical modeling, psychological analysis, political forecasting, political modeling, content analysis, case study.

Key words: methodology, methodological approach, method, presidential power, legitimacy, political technologies, delegitimation, technologies of delegitimation of presidential power. 
Постановка проблеми. Трендами політичного процесу України сьогодення є загострення політичної кризи та радикалізація проявів невдоволення народних мас. Рівень недовіри громадян до політичних та державних інститутів стає загрозливим. За таких умов дослідження технологій делегітимації президентської влади набуває величезного значення. Недостатній рівень висвітлення вищезазначених проблем у вітчизняній науковій літературі спонукає нас запропонувати дієвий інструментарій для наукового дослідження проблем делегітимації президентської влади.

Аналіз останніх досліджень і публікацій. Розробленню методології дослідження проблем легітимності та делегітимації політичної влади присвячено праці таких зарубіжних учених, як Т. Парсонс, Д. Істон, Г. Алмонд, С. Ліпсет та ін. Проблематика делегітимації президентської влади та кризи легітимності влади в політичному процесі України досліджувалася у працях таких українських науковців, як Є. Цокур, І. Рибак, К. Ващенко, Р. Ключник та ін.

Мета статті - дослідити методологічні підходи до дослідження технологій делегітимації президентської влади. Для досягнення поставленої мети було виконано такі завдання: проаналізовано можливості застосування для дослідження технологій делегітимації президентської влади загальнонаукових методологічних підходів, досліджено евристичний потенціал спеціальних методів політичної науки та міждисциплінарних методів суміжних наукових галузей, в яких досліджуються проблеми делегітимації влади та технологізації управління соціально-політичними процесами.

Виклад основного матеріалу. Рівні методології наукового дослідження задають рамки для систематизації методів пізнання. Філософський рівень $є$ фундаментальним - у його межах визначаються світоглядні підходи до процесу пізнання. Загальнонауковий рівень методології виступає з'єднувальною ланкою між фундаментальними філософськими принципами та конкретними спеціальними методами наукових досліджень. У його межах застосовуються теоретичні концепції, притаманні науковим розвідкам переважної більшості наук. У рамках конкретно-наукового рівня визначаються можливості та умови використання спеціальних методів політичної науки та спеціальних методів суміжних наукових галузей (за умови доцільності їх застосування до конкретного предмету дослідження).

Зупинимося детальніше на особливостях застосування загальнонаукових підходів та конкретнонаукових методів дослідження технологій делегітимації президентської влади. У рамках загальнонаукового рівня методології в нашому дослідженні розглянуто такі традиційні та модерні (сучасні) підходи та методи наукового пошуку: інституційний, історичний, соціокультурний, аксіологічний, системний, біхевіоральний, діяльнісний, синергетичний.

Дослідження технологій делегітимації президентської влади передбачає розгляд політичних інститутів як сталих форм організації державної влади, тому інституиійний підхід є ключовим для дослідження проблем делегітимації президентської влади. Інституційний підхід пов'язує делегітимаційний процес із трансформацією інститутів влади та зі зміною політичного лідера, який уособлює інститут президентства у певний період часу. Цей підхід можна використовувати в процесі аналізу юридичних норм і законів (наприклад, Конституція України, Виборчий кодекс України та ін.) та їх значення у контексті застосування технологій делегітимації президентської влади. Ми концентруємо увагу на делегітимації саме президентської влади, адже явище легітимності в українському політичному процесі має персоніфікований характер. Такої позиції дотримується й Є. Цокур: він уважає, що українська модель легітимності та легітимації здебільшого виявилася персоналізовано-технологічною. Тобто суспільство визнавало обгрунтованими претензії певних особистостей і груп на владу, виходячи не з їх державотворчого суспільно-консолідуючого потенціалу, а зважаючи на їхні особистісні якості й технології, які використовувалися для легітимізації їх владних зазіхань. Тому перманентні кризи легітимності стали ознакою української політичної системи. Протягом тривалого часу українська державність, шлях до якої був тернистим та навіть трагічним, доволі швидко і без зайвого жалю з боку суспільства втрачалася. Причому головною причиною делегітимації власної політичної системи, еліти, лідерів та руйнації державності, як не парадоксально, ставало саме суспільство [1, с. 66]. Україні притаманна політична система лідерського типу - роль лідера у функціонуванні політичних інститутів (від окремих політичних партій до держави загалом) часто є домінуючою. На думку С. Ліпсета, такі системи більш уразливі до делегітимаційних впливів, тому що люди втрачають довіру до своїх лідерів значно легше, ніж довіру до системи [2, с. 378]. У західних країнах сталої демократії влада має абстрактну природу, тобто відділена від особи правителя, тоді як Україна відноситься до країн, де влада має персоніфікований характер і безпосередньо пов'язана з особою-носієм. Погоджуємося з І. Рибак, яка наголошує на тому, що головною закономірністю впроваджуваних делегітимаційних технологій є ескалація політичного протистояння в Україні в інформаційно-комунікативній сфері. Причому передусім на рівні політичних особистостей, а вже потім негативна інформаційна проєкція від особистості транслюється на його 
політичні ідеї, політичну силу, програму, оточення, навіть прибічників. Останнє особливо небезпечно, оскільки створює чимало загроз світоглядного розколу української нації [3, с. 408].

Історичний niдxiд являє собою сукупність методів, які дають змогу дослідити технології делегітимації президентської влади в часових межах українського політичного процесу крізь призму функціональних процесів і структурних змін, які відбулися в політичній системі України за часи незалежності, та набуття нею тих якостей, які характеризують ії політичні інститути на сучасному етапі державного будівництва. Методичний арсенал історичної науки забезпечує нас можливостями для використання методу періодизащії - за його допомогою можна дослідити особливості застосування технологій делегітимації президентської влади у відповідних періодах, виділених на основі чітко визначених критеріїв проміжках часу. На основі ретроспективного методу доцільно визначати історичні передумови розгортання делегітимаційних процесів у чітко визначених хронологічних межах.

Соціокультурний niдxid є доволі новим для політичних досліджень, він спонукає до концентрації уваги на стратегічних соціально-політичних цілях історичного відтворення українського суспільства 3 урахуванням його національної культурної специфіки. Такий підхід розширює можливості для багатофакторного аналізу українського соціокультурного простору в контексті виявлення механізмів впливу політичної культури на делегітимаційний процес. Аксіологічний nidxid тісно пов'язаний із соціокультурним, адже базується на дослідженні цінностей, які були сформовані в процесі об'єктивного історично-культурного розвитку суспільства. Такий підхід буде помічним у визначенні ролі цінностей (у формі норм та ідеалів), у технологіях мотивації й спонукання суспільства до певних форм політичної участі та їх впливу на мотиви політичного вибору [4, с. 76-77].

Системний niдxid дає змогу дослідити делегітимаційний процес як динамічну цілісність, елементи якої пов'язані між собою за допомогою структурно-функціонального зв'язку. Запровадження системного підходу в політичній науці пов'язано з іменами таких науковців, як Т. Парсонс, Д. Істон та Г. Алмонд. Системний підхід до дослідження соціальних систем уперше був застосований Т. Парсонсом у праці «Про соціальні системи» (1951р.). У центрі уваги вченого знаходяться концепції взаємозв'язків та взаємовпливів між елементами соціальної системи. Особливу увагу у цій праці автор приділив дослідженню мотивації політичної участі індивіда в контексті визнання та підтримки політичної влади, усталених у суспільстві традицій та норм, а також механізмам впливу на поведінку індивіда з метою іiі спрямування на підтримку стабільності системи $[5$, с. 77-78]. У політичну науку системний підхід привніс Д. Істон. Саме він є засновником теорії політичних систем. У своїх працях він наголошує на необхідності застосування інтегративного принципу в дослідженнях політичної сфери життя суспільства. Згідно із цим принципом, політичні процеси, перебуваючи у перманентному взаємозв'язку, відіграють роль системоутворюючих взаємовідносин між елементами політичної системи [6, с. 383-384]. Учений акцентує увагу на важливості політизації членів суспільства, під якою він розуміє процес засвоєння політичних цінностей та норм політичної поведінки для забезпечення відчуття легітимності політичної системи у свідомості людей [6, с. 397]. Д. Істон розробив модель взаємодії політичної системи із зовнішнім середовищем, згідно з якою політична система активно впливає на середовище з метою самозбереження та розвитку й зазнає зворотного впливу від нього. Також його авторству належить концептуальна модель політичної системи, яка складається 3 «входу», «виходу» та «чорного ящику», у якому відбувається обробка «вхідних» запитів та реакція на зміни у середовищі з подальшою їх конверсією у форму політичних рішень та дій, спрямованих на їх реалізацію, на «виході» із системи. Г. Алмонд розвинув та поглибив напрацювання Д. Істона в сенсі застосування системного підходу в політичних дослідженнях [7]. У концепціях Г. Алмонда базовою одиницею політичної системи виступає «політична роль». У своїх працях він намагається встановити відповідність між політичним режимом та політичною культурою та виявити ключові взаємовпливи між ними. Провівши історично-компаративне дослідження політичних культур США, Мексики, Великобританії, Германії та Італії, він установив найбільш відповідні та сприятливі для стабільного функціонування декоративних систем політичні культури [8, с. 14]. Метод системного аналізу також застосовують для пошуку шляхів та способів інтеграції методів і результатів дослідження суміжних дисциплін (психологія, статистика та ін.) у розроблення технологій делегітимації президентської влади; розроблення методик та прийомів моделювання делегітимаційного процесу [9, с. 17].

Біхевіоральний nidxid допомагає у дослідженні проєкції індивідуального виміру політичної поведінки на групові форми політичної діяльності. За його допомогою встановлюють домінуючі мотиви участі та особливості політичної орієнтації електорату, досліджують теорії та моделі політичної поведінки індивідів та їх груп, які мають евристичну та прогностичну цінність, інтерпретують явище делегітимації та визначають необхідні для управління делегітимаційним процесом технології відповідно до 
мотивів політичного вибору, зразків політичної поведінки та практик політичної участі. Це має велике значення для вивчення делегітимаційних технологій, адже дає можливість установити вихідні чинники формування та спрогнозувати й оцінити можливі наслідки делегітимаційного процесу.

Підгрунтям застосування діяльнісного підходу є предметна діяльність людини (групи людей, соціальних спільностей, суспільства у цілому). Вона виступає у формі активності, що має потенціал до впливу на зміни у політичному житті суспільства. За цього підходу політичні технології розглядають як множину конкретних прийомів, дій та їх алгоритмів - одиниць діяльності, за допомогою яких досягається мета діяльності; остання складається із завдань - потреб і запитів суспільства, які можуть бути вирішені за допомогою певним чином структурованої діяльності.

Синергетичний nidxid у дослідженні технологій делегітимації президентської влади полягає у вивченні механізмів становлення і збереження президентської влади. Зокрема, розглядаються стани стійкої нерівноваги інституту президента по відношенню до інших елементів політичної системи та зовнішнього середовища. На базі синергетичного підходу досліджують кризи та біфуркації легітимності президентської влади - нестійкі фази функціонування, які передбачають множинність сценаріїв подальшого розвитку. Для ефективного застосування цього підходу необхідно здійснити такі кроки: визначити предмет синергетичного впливу - інститут, систему та процес на який $є$ намір здійснити вплив за допомогою делегітимаційних технологій, проаналізувати можливі альтернативи розвитку предмету впливу, встановити чинники його самоорганізації, визначити бажаний результат синергетичного впливу, розробити технології, які здійснюватимуть цілеспрямований вплив на самоорганізацію предмету впливу, визначити точки біфуркації, які можуть бути найбільш сприятливими для впливу політичних технологій делегітимації президентської влади [4, с. 70-75].

У межах конкретно-наукового рівня методології для дослідження технологій делегітимації президентської влади ми пропонуємо послуговуватися методами спостереження, статистичного аналізу, математичного моделювання, психологічного аналізу, політичного моделювання, політичного прогнозування, контент-аналізу, case study.

Метод спостереження використовують для вивчення політичних практик застосування делегітимаційних технологій. Характерною ознакою наукового спостереження $є$ його цілеспрямованість на підтвердження або спростування за результатами дослідження ідей та гіпотез, які були висунуті на його початку та були основою для визначення завдань дослідження. Наприклад, гіпотези про те, що специфікою застосування технологій делегітимації президентської влади в українському політичному процесі $є$ їхній негативний вплив не лише на персону конкретного політика (який виражається у зниженні довіри суспільства до нього), а й на інститут президентства як такий. Методи статистичного аналізу та математичного моделювання стануть у нагоді під час математичної формалізації зібраного матеріалу соціологічних досліджень, відслідковування у них певних тенденцій та кореляцій. Отримані цими методами результати будуть визначальними для надання політичних прогнозів щодо наслідків застосування технологій делегітимації президентської влади в українському політичному процесі та рекомендацій із використання конкретних методів протидії негативним впливами таких технологій. Метод психологічного аналізу стане дороговказом під час вивчення суб'єктивних механізмів політичної поведінки, прийомів психологічної мотивації та технологій маніпулювання свідомістю мас. Застосування методу політичного моделювання полягає у дослідженні делегітимаційних процесів і явищ шляхом конструювання та вивчення їх моделей. Суть методу полягає у вивченні штучного аналога об'єкта дослідження - моделі. На цій підставі делегітимаційний процес відображається у вигляді логічних схем. Моделювання делегітимаційного процесу здійснюють не лише на підставі вже відомих, емпірично перевірених даних, а й на основі гіпотез. Моделювання гіпотез і проведення теоретичного аналізу отриманих моделей дає змогу, з одного боку, перевірити гіпотези на несуперечність, з іншого - виявити чутливі та важливі параметри моделі, ті ознаки і зв'язки, зміни яких мають найсуттєвіший вплив на вихідні параметри моделі [10, с. 11-14]. Метод політичного прогнозування застосовують у частині окреслення перспектив практики застосування технологій делегітимації президентської влади в українському політичному процесі. Як слушно зауважує К. Ващенко, прогноз у сфері політики не стільки відіграє роль традиційного пророцтва, скільки є технологією, котра вказує, за яких умов і за допомогою яких засобів можна буде досягнути бажаного майбутнього [11, с. 168]. Опрацювання першоджерел, у тому числі нормативно-правових актів, промов та інтерв'ю політичних діячів, здійснюють на основі методу контент-аналізу. Метод case study уможливлює накопичення емпіричного матеріалу з метою його подальшого аналізу, обробки та узагальнення. За його допомогою можна розглядати численні приклади виникнення, розвитку і вирішення кейсів делегітимації президентської влади. 
Він буде помічним у визначенні загальної тенденції під час розгляду окремих випадків реалізації делегітимаційних політичних технологій [12, с. 109-110].

Висновки. Висвітлені у статті методологічні підходи та методи дослідження відкривають широкі перспективи для подальшого наукового пошуку в напрямі конструювання технологій делегітимації президентської влади та розроблення практичних рекомендацій щодо протидії негативному впливу цих технологій на інститут президентства.

\section{Література:}

1. Цокур Є.Г. Загальна модель та особливості легітимації політичної влади. Політичний менеджмент. 2010. № 1. C. 61-67.

2. Lipset S.M. The Confidence Gap: Business, Labor, and Government in Public Mind. Baltimore : Johns Hopkins University Press, 1983. $434 \mathrm{p}$.

3. Рибак І.В. Інформаційно-маніпулятивні технології політичної делегітимації в Україні: позаелекторальний контекст. Науковий часопис НПУ імені М.П. Драгоманова. Серія «Політичні науки та методика викладання соиіально-політичних дисииплін». 2014. Спец. вип. С. 406-412.

4. Савченко В.Ф., Шестаковська Т.Л. Наукове дослідження: задум, реалізація, результати : монографія. Мена : Номінант, 2013. $256 \mathrm{c.}$

5. Парсонс Т. О социальных системах / пер. с англ. В.Ф. Чесноковой. Москва : Академический проект, 2002. 832 с.

6. Easton D. An Approach to the Analysis of Political Systems. World politics. 1957. № 9. P. 383-400.

7. Алмонд Г.А., Верба С. Гражданская культура и стабильность демократии. Политические исследования. 1992. № 4. C. $122-134$.

8. Almond G.A., Verba S. The Civic Culture: Political Attitudes and Democracy in Five Nations. Princeton, New Jersey : Princeton University Press, 1963. 562 p.

9. Теоретические основы системного анализа / под. ред. В.И. Новосельцева. Москва : Майор, 2006. 592 с.

10. Політологія (модульний курс) : навчальний посібник / Б.О. Галь та ін. Дніпро : Національний гірничий університет, 2013. $141 \mathrm{c}$.

11. Ващенко К.О. Основні форми і принципи дослідження політичного аналізу й прогнозу. Політичний менеджмент. 2007. № 1. C. $165-172$.

12. Ключник Р.М. Криза у політичній системі: проблеми методології дослідження. Вісник Дніпропетровського університету. Серія «Філософія. Соиіологія. Політологія». 2015. № 2. С. 105-111. 